\title{
Evaluation Of The Success Of Population, Family Planning, And Family Development Program
}

\author{
Agung Biworo*, Lenie Marlinae**, Syamsul Arifin**, Laily Khairiyati**, Agung Waskito**, \\ Anugrah Nur Rahmat**, Herty Sasmieta***, M Gilmani**, Winda Saukina Syarifatul Jannah**, \\ Raudatul Jinan**
}

\begin{abstract}
*Medical Education Study Program, Faculty of Medicine, Lambung Mangkurat University, Indonesia
**Public Health Study Program, Faculty of Medicine, Lambung Mangkurat University, Indonesia *** Faculty of Medicine, Lambung Mangkurat University, Indonesia
\end{abstract}

DOI: 10.29322/IJSRP.11.07.2021.p11587

http://dx.doi.org/10.29322/IJSRP.11.07.2021.p11587

\begin{abstract}
There are several problems faced related to the not yet optimal implementation of the Population, Family Planning, and Family Development (KKBPK) program in the field, including: a. The number of KKBPK extension workers in the field continues to decrease due to mutations, promotions and retirements. b. The low independence of family planning $\mathrm{c}$. The role of the Bina Keluarga Sejahtera (BKS) group cadres has not been optimal in the success of KB for its members who are still in PUS, as well as the role of toga, toma, cadres and professional organizations. d. The role of the Village Head in the KKBPK program is not yet optimal, both in motivating the community and in providing budgetary support for the KB-KS program. The total number of articles obtained was 5,080. After the articles were excluded because they did not meet the inclusion criteria, 17 articles were found that were suitable for review.
\end{abstract}

Index Terms- Input, Output, Population, Family Planning, and Family Development (KKBPK) program

\section{INTRODUCTION}

The Population, Family Planning and Family Development Program (KKBPK) has a mission to carry out family development with a productive economy and the implementation of family functions. To become a quality family, Indonesian families must follow the Family Planning (KB) program that has been launched by the government. Quality family indicators are measured by increasing family resilience and welfare based on the implementation of 8 (eight) family functions. Among them are religious functions, sociocultural functions, love functions, protection functions, reproduction functions, socialization and education functions, economic functions and environmental development functions (Januar AS, 2020).

According to the Government's Performance and Accountability Survey (SKAP) for the 2019 KKBPK program, the achievements are concerning. Only one of the five strategic targets of the KKBPK program in 2019 can meet and even exceed the target, namely the use of MKJP can reach $24.6 \%$ of the $23.5 \%$ target. The total birth rate which is expected to decrease to 2.28 per WUS aged 15-19 years, actually shows an increase to 2.45. Likewise, the use of modern contraception fell to $54.97 \%$ from the previous year's $57 \%$. The drop-out rate shows the same number as the 2017 IDHS achievement of $29 \%$, an increase of $4 \%$ from 2018. Unmet need achievement does not move at $12.1 \%$ (BKKBN, 2020).

Based on the results of budget realization performance for the physical Special Allocation Fund (DAK) scheme and Family Planning Operational Costs (BOKB) in 2018, of the total ceiling of the 2018 DAK Activity Plan and Budget for 479 Regencies/Cities in Indonesia, the Regency/City governments are only able to realize it by $79 \%$. There is special attention in 6 (six) provinces with less than $70 \%$ realization, one of which is in South Kalimantan (BKKBN, 2020).

The implementation of the Population, Family Planning and Family Development Program (KKBPK) so far has not run optimally both in the aspects of cultivating the Maturity of Marriage Age (PUP), Birth Control, Family Resilience Development, Family Economic Empowerment, and Population Management which is marked by the still high rate of growth. population, early marriage, non-fulfillment of new acceptor achievement targets, low family participation in Family Welfare Development (BKS) and Prosperous Family Income Improvement Efforts (UPPKS) (Sudarmi, 2020).

There are several problems faced related to the not yet optimal implementation of the KKBPK program in the field, including: a. The number of KKBPK extension workers in the field continues to decrease due to mutations, promotions and retirements. $b$. The low independence of family planning $c$. The role of the Bina Keluarga Sejahtera (BKS) group cadres has not been optimal in the success of KB for its members who are still in PUS, as well as the role of toga, toma, cadres and professional organizations. d. The role of the Village Head in the KKBPK program has not been optimal, both in motivating the community and in providing budgetary support for the KB-KS program (Sudarmi, 2020).

\section{IDENTIFY, RESEARCH AND COLLECT DATA}

Article searches are carried out using a search engine using Google Scholar with the keywords used are Human Resources (HR), facilities and infrastructure, financing, planning accuracy, implementation mobilization, monitoring and assessment, feedback, community capacity index in the Population, Family Planning program, and Family Development (KKBPK). The total number of articles obtained was 5,080. After the articles were excluded because they did not 
meet the inclusion criteria, 17 articles were found that were suitable for review.

\section{DISCUSSION}

\section{A. Evaluating the Human Resources (HR) of the KKBPK Program}

According to Muchlis S and Maron A's research in 2018 the lack of human resources is a factor that affects the program implementation not yet maximized, judging from the human resources that affect it is still limited so that the existing human resources must have concurrent duties. The overlapping of tasks faced tends to hamper the performance of the office in encouraging the successful achievement of the KKBPK program goals (Muchlis S and Maron A, 2018). Based on research by Resnawaty R, Humaedi S, and Adiansah W in 2018 looking at several aspects that are reviewed from the Kampung $\mathrm{KB}$ program, from the input aspect it must involve many sources, one of which is human resources, the contents of which are PLKB/TPD (Family Planning Field Extension Officers). Village Movers), Village Midwives, Cadres, Youth Youth Organizations, Religious Leaders, Community Leaders, and community beneficiaries of $\mathrm{KB}$ Village (Resnawaty R, Humaedi S, and Adiansah W, 2018).

According to research by Mandas IST, Lengkong FDJ, and Ruru $\mathrm{J}$ in 2018, the family planning program is sufficient to help the government, but in its implementation the problems that often occur are related to the human resources of medical personnel, which must be further improved, especially in providing services directly to the community. Friendly, fast and precise service is the benchmark for SOPs. As for the efforts made by the government to maximize the results of the family planning program, namely by actively carrying out socialization and increasing publications to invite the community to participate in this program in order to create a prosperous family and also actively conducting seminars to the community on healthy reproduction in addition to improving education and training. training, for field officers and managers in each district/city (Mandas IST, Lengkong FDJ, and Ruru J, 2018). Meanwhile, according to research by Zuhriyah A, Indarjo S, and Raharjo BB in 2017, the Family Planning Field Extension Officer (PLKB) assigned to foster the Dadapsari kelurahan not only fostered one kelurahan but there were 5 kelurahan that were fostered so that PLKB officers became less effective and less focused in implement coaching so as to hinder the success of the program. According to Pasrah in Zuhriyah A, Indarjo S, and Raharjo BB in 2017, the inhibiting factors for the success of the family planning program include the low resources owned by agencies related to the implementation of family planning programs. According to Grestina in Zuhriyah A, Indarjo S, and Raharjo BB in 2017, one of the inhibiting factors for the success of the family planning program is the lack of family planning field officers which results in a lack of socialization and counseling about family planning programs, factors that affect empowerment in human resource development projects include: the existence of self-sources and abilities in the form of modeling, motivation, and support (Zuhriyah A, Indarjo S, and Raharjo BB, 2017).

According to research by Simanjuntak I, Nugraha T, and Simanjorang A in 2020 Government Regulation No. 87 of 2014 concerning population development and family development, family planning, and information systems states that the regulation of population development and family development is to improve the quality of families in order to create a sense of security, peace and stability., and hope for a better future in realizing physical prosperity and inner happiness by institutionalizing and civilizing the norms of a small, happy, and prosperous family. For this success, potential human resources, especially Family Planning Field Extension Officers (PLKB) need to be improved. In addition, there is a need for participation from community institutions (religious leaders, community leaders, and non-governmental organizations) in family planning programs (Simanjuntak I, Nugraha $T$, and Simanjorang A, 2020). According to research by Raharjo EG and Solomon RV in 2019, not all of the human resources of the apparatus are still young. Many of the KKBPK extension workers in Banten Province are elderly. Seventy-six percent of KKBPK extension workers in Banten Province are fifty years of age and over. This causes a low understanding of technology because the application of E-Visum is an application of egovernment. This lack of understanding of the technology field makes civil servants a little longer in understanding what and how to apply this E-Visum. There are even some KKBPK extension workers who need assistance in running the E-Visum application (Raharjo EG and Solomon RV, 2019).

According to research by Lettiyani $\mathrm{E}$ and Kencana $\mathrm{N}$ in 2020, it shows that human resources in supporting the success of the KB village program in Hamlet I, Sribunga Village, are still lacking. Human resources in terms of quantity or number of $\mathrm{KB}$ village administrators in Sribunga Village are still lacking because the PPKBD/SUB PPKBD still holds two positions at once. In the resource indicators contained in the $\mathrm{KB}$ village program in Sribunga Village, it is not yet adequate in its implementation. This is because the implementor still has shortcomings and the educational background is also low, namely the average junior high school education, and this causes one person to hold two positions and functions, and for the target group it is sufficient (Lettiyani E and Kencana N, 2020). According to research by Istiadi A and Rosdiana W in 2012 human resources are one of the factors in supporting the success of a program. In this KB village activity in Waung Hamlet, there is no shortage of human resources. This is because the implementers of Kampung KB in Waung Hamlet do not feel lacking in terms of human resources, because there are 20 Cadres who participate and also support from religious leaders and community leaders as well as from village officials is sufficient in implementing KB Village activities (Istiadi A. and Rosdiana W, 2012). Another thing is the lack of cooperation between human resources who run it. This condition is because the key to the success of Kampung KB is the coordination of all parties, including the government, the private sector, and the community. In addition, human resources are the most important supporting factor in the Family Planning Program Village. Resource facilities play an important role in supporting and supporting the implementation of the village family planning program (Handayani A, Najib, Ardini SN et al, 2020).

This is in accordance with the conceptual framework which states that the evaluation of the success of the KKBPK program is influenced by input factors, namely from the Human Resources (HR) factor which states that the HR sub-indicators support the needs and support the success of the KB Village Program.

\section{B. Evaluating KKBPK Program Facilities and Infrastructure}

According to research by Resnawaty R, Humaedi S, and Adiansah W in 2018 on the aspect of environmental facilities/infrastructure with the existence of KB Village, 
environmental facilities/infrastructure are getting better in quality and quantity. The facilities and infrastructure available for the KB Village itself are as follows: Secretariat of UPT DP2KBP3A Gunung Jati District, Dataku House, Posyandu, Schools (TK/PAUD, Elementary and Junior High School), Mosque and Musholla, Village road facilities (Resnawaty R, Humaedi S, and Adiansah W, 2018). Meanwhile, based on research by Rianto F, Nengsih NS, and Setyadiharja R in 2019, the availability of operational facilities such as office buildings or secretariats as well as other supporting facilities, is one of the most important input indicators for the success of the KKBPK Program in KB Village. Operational facilities such as the KB Village secretariat building are already available in each $\mathrm{KB}$ Village, but are limited. The limited operational facilities are located in the office building or secretariat of Kampung KB which rides on other buildings such as Posyandu, Polindes, Extension Centers, or other buildings (Rianto F, Nengsih NS, and Setyadiharja R, 2019).

According to research by Simanjuntak I, Nugraha T, and Somanjorang A in 2020 there are obstacles in the implementation of the Kampung $\mathrm{KB}$ program including inadequate facilities, such as a place or room to carry out counseling or socialization of the Family Planning (KB) program (Simanjuntak I, Nugraha $T$, and Somanjorang A, 2020). Meanwhile, according to research by Ramdana S, Kusuma AR, and Apriani F in 2018 activities that cannot be carried out due to lack of facilities and infrastructure. Therefore, advocacy for all UPDs and Related Agencies should be increased so that they can support the implementation of the KKBPK program activities in the Sector of Family Welfare and Resilience. Both support in the form of materials and facilities and infrastructure or other forms of support. As all UPDs are responsible for the success of the KKBPK Program. In other words, the importance of a synergistic role between the City DPPKB and relevant agencies in the implementation of the KKBPK program (Ramdana S, Kusuma AR, and Apriani F, 2018).

According to research by Lettiyani E, Isabella, and Kencana $\mathrm{N}$ in 2020, facility resources are facilities and infrastructure to support the implementation of the KBB village program, which is appropriate for the successful activities of the $\mathrm{KB}$ village program. This was explained by the respondents that the existing facilities in the $\mathrm{KB}$ village were sufficient for the implementation of activities. For example, the place used is the data house, and each activity is carried out not only at the data house, it can be at the village hall, at the homes of cadres or other administrators who are willing and for other facilities also available, no complaints from the management. and the community, besides that the administrators also did not complain about the facilities to support the activities (Lettiyani E, Isabella, and Kencana N, 2020). Meanwhile, according to research by Istiadi A and Rosdiana W in 2012, proper facilities and infrastructure were provided to support the success of the Family Planning Village program. It has been explained by the respondent that the facilities or infrastructure used in supporting the process of implementing the KB Village Program activities is one of them, namely the place. The place used during the activity is located in the houses or residence of one of the residents who are willing, sometimes also when there is counseling, the place used is in the village hall. In addition, other facilities and infrastructure are also provided, such as counseling books intended for cadre mothers to provide guidance to the community. Other facilities are also provided to toddlers who take part in the $\mathrm{KB}$ village activities, the facility is the Educational Game Tool (APE) which is useful for sharpening facility resources which have an important role in supporting and supporting the running of the KB Village Program (Istiadi A and Rosdiana W, 2012).

This is in accordance with the conceptual framework which states that the evaluation of the success of the KKBPK program is influenced by input factors, namely from the Facilities and Infrastructure factor stating that facility resources have an important role in supporting and supporting the running of the KB Village Program.

\section{Evaluating KKBPK Program Financing}

According to research by Rianto F, Nengsih NS and Setyadiharja $\mathrm{R}$ in 2019, the lack of a budget also creates its own challenges where PKB/PLKB sometimes use privately owned funds or expect from non-governmental organizations or subdistrict assistance for operational activities. The reluctance of the community to participate in KB Kampung activities or to become KB Village cadres as PPKBD/Sub-PPKB or to be involved in KB Kampung POKJA, can also be attributed to the lack of financial incentives or stimulants available to $\mathrm{KB}$ Village cadres. Therefore, local governments need to show their role and concern for KB Villages by allocating part of the budget for KB Village operations or facilitating the distribution of CSR funds from other funding sources for the KB Village Program (Rianto F, Nengsih NS, Setyadiharja R, 2019). Meanwhile, according to research by Resnawaty R, Humaedi S, and Adiansah W, in 2018, the funding for the KB Village at the time of its first declaration came from the central BKKBN. Furthermore, funding for various programs and activities comes from various offices that support KB Village programs and activities. In addition, funding also comes from the Village Fund. For the 4th year, the TPD and the KB Village administrators seek community self-help funds to support the implementation of various KB Village programs and activities. Each beneficiary who received services in these activities was asked voluntarily to set aside money as a form of gratitude for the services received (Resnawaty R, Humaedi S, and Adiansah W, 2018).

According to Muchlis S and Marom A's research in 2018 the problem of cost or budget and internal problems such as lack of human resources are factors that influence the implementation of this program, plus other factors such as poverty also affect community participation with the program, but steps taken by the Department Population Control and Family Planning to cover this shortfall is by collaborating with other parties, such as community groups, NGOs, and even other agencies that both focus on the welfare of the community (Muchlis S and Marom A 2018). In the 2018 research by Mandas IST, Lengkong FDJ, and Ruru $J$, the cost of participating in the family planning program is comparable to the services provided through complete facilities in the field and Alkon (contraceptive devices and drugs) of high quality and guaranteed safety. talking about efficiency, the budget used for family planning programs ranging from family coaching, alkon and others is not too expensive (Mandas IST, Lengkong FDJ, and Ruru $\mathrm{J}$ in 2018). While research by Zuhriyah A, Indarjo S, and Raharjo BB in 2017 the funds used in family planning village activities are funds originating from the Regional Budget (Regional Revenue and Expenditure Budget) amounting to Rp. These funds are funds used for preparation to the establishment of a family planning village. In the technical instructions for the formation of a family village, the fund is a budget provided by 
the BKKBN for the formation process and the fund is a stimulant fund and is allocated to the DIPA (Budget Implementation List) representatives of the Provincial BKKBN (Zuhriyah A, Indarjo S, and Raharjo BB, 2017).

According to research by Ramdana S, Kusuma AR, and Apriani F in 2018 the lack of budget resulted in training and orientation to cadres in preparing cadres cannot be carried out. And other activities cannot run optimally because of inadequate facilities and infrastructure such as secretariat, manuals and so on. For Poktan UPPKS still need capital development. So that one must pay more attention to the budget, one of which is by continuing to support in the form of capital development for Poktan. Because the lack of a budget affects the implementation of the KKBPK program activities, one of which affects the quality of cadres due to the difficulty of holding training for these cadres (Ramdana S, Kusuma AR, and Apriani F, 2018). Research by Istiadi A and Rosdiana W in 2012 said that budgetary resources are resources that involve issues regarding funds or initial capital that have been planned in advance within a certain period of time which will later be allocated in an activity. The results of the research related to the budget used were sufficient to cover the existing funding needs during the Kampung KB program process. The budget itself comes from the APBD, ADD, and also from the Provincial BKKBN. For the declaration, namely in the form of gate construction and the need for socialization, it was initially financed by the Provincial $\mathrm{BKKBN}$, then for subsequent activities, namely in the need for consumption, counseling, and transportation money for cadres, it came from the APBD budget and was also assisted by ADD (Istiadi A and Rosdiana W, 2012).

This is in accordance with the conceptual framework which states that the evaluation of the success of the KKBPK program is influenced by input factors, namely from the Financing factor stating that funding and budgets have an important role in supporting and supporting the running of the KB Village Program.

\section{Evaluating the Accuracy of KKBPK Program Planning}

BKKBN to re-earth the Population, Family Planning, and Family Development (KKBPK) program is to continue to build $\mathrm{KB}$ Villages throughout Indonesia. $\mathrm{KB}$ village is an area unit at the level of RW, hamlet or equivalent, which has certain criteria where there is an integration of the KKBPK program and related sector development which is carried out systematically and systematically (Khotimah K, Ratnasari V, Ratna M, 2018).

Based on the results of research by Resnawaty R, Humaedi S, and Adiansah W in 2018 from the process aspect, it consists of various activities starting from the pre-declaration stage, the declaration stage and the post-proclamation stage. The pre-declaration stage consists of building commitments, preparing regional profiles, determining the area as $\mathrm{KB}$ Villages, forming $\mathrm{KB}$ working groups, providing data and information and planning programs and activities. The declaration stage consists of the launching/inauguration of the $\mathrm{KB}$ Village. While the post-declaration stage contains various operational activities for the KB Village, starting from data collection and family mapping, RT level meetings, hamlet level meetings, implementation of KB Village programs and activities and recording and reporting. In the process, aspects that need attention are efforts to increase community participation (Resnawaty R, Humaedi S, and Adiansah W, 2018).

This is in accordance with the conceptual framework which states that the evaluation of the success of the KKBPK program is influenced by the Planning Accuracy Factor stating that careful and perfect planning has an important role in supporting and supporting the running of the KB Village Program.

\section{E. Evaluating the Movement for the Implementation of the KKBPK Program}

Research by Resnawaty R, Humaedi S, and Adiansah W in 2018 The Village Movers (TPD) basically work on the scope of the Village, the TPD focuses on various activities. Meanwhile, the activities that have been carried out in the village scope are only limited to socialization activities related to the use of contraception. The challenge faced by the TPD is the challenge of the differences in characteristics and culture between the TPD and the people of Kampung KB. In addition, the workload is not proportional to the number of TPD currently available. Village Midwives Mobilizing Forces who from the beginning of the declaration accompanied KB Villages. Based on the duties and functions, the role of the village midwife in the Kampung KB program is basically a very strategic role. This is because most of the programs and activities in Kampung KB are programs that are closely related to the health aspect (Resnawaty R, Humaedi S, and Adiansah W, 2018).

In addition, the Community Leaders Mobilization Force consists of religious leaders, government figures ranging from RT, RW, Village Heads, youth and youth leaders of Karang Taruna. These community leaders become local agents who can invite and encourage the community to raise awareness of the importance of the KB Village program and foster community participation to participate in various KB Village programs and activities. The problems that occur in the community leaders are not much different from the problems in the cadres. When there is a change of village head, community leaders in the field of government starting from the Head of RT, Head of RW also change. This certainly has an impact on the KB Village, the change will certainly result in policy changes at the local level. This prompted the TPD and village midwives to make efforts to re-approach these new government figures. As much as possible, various previous policies that have been good should not be changed (Resnawaty R, Humaedi S, and Adiansah W, 2018). The status of community leaders as parties who socialize the program is needed so that the community can receive the program well. In addition, internalizing an understanding of the importance of the program will be easier for people who are known and respected (Yunas NS and Nailufar FD, 2019).

The Population, Family Planning, and Family Development Program (KKBPK) can be implemented optimally if there is a commitment at the leadership level for stunting prevention in $1000 \mathrm{HPK}$. The commitment of the leadership from the center to the regions is needed, because the right of children to get health (not stunting) is a human right that is protected by the state. Government efforts involving multisector not only the Ministry of Health but with the National Population and Family Planning Agency (BKKBN) in stunting prevention is the right step. Strengthening in the KKBPK program related to the campaign for setting a minimum birth interval of 24 months (first child with subsequent births), needs to be intensified as a stunting prevention campaign. This campaign can be strengthened by making it a national stunting prevention movement that involves cross-sectoral and leadership commitments or stakeholders in related institutions (Mauluddin A and Novianti, 2020).

This is in accordance with the conceptual framework 
ISSN 2250-3153

which states that the evaluation of the success of the KKBPK program is influenced by the Implementation Mobilization Factor. support and support the running of the KB Village Program.

F. Evaluating the Supervision and Assessment of the KKBPK Program

Based on the research of Rianto F, Nengsih NS, and Setyadiharja R in 2019, the Family Planning Village Program in Tanjungpinang City was considered to have gone well. This is indicated by the majority of respondents stating that the Kampung KB Program has been running well, and the people of Kampung KB receive family planning services and health services in addition to participating in the activities carried out in the KB Village. Cross-sectoral activities such as collecting data and making birth certificates and Identity Cards (KTP) in collaboration with the Department of Population and Civil Registration (DISDUK CAPIL) of Tanjungpinang City, such as those carried out in Tanjung Unggat KB Village and Dompak Lama Village, are examples of cross-sector collaboration sectors that complement the services and activities of the $\mathrm{KB}$ Village Program. However, the scope of KB Village activities needs to be intensified in order to reach more people in $\mathrm{KB}$ Villages (Rianto F, Nengsih NS, and Setyadiharja R, 2019).

The results of Muchlis S and Maron A's 2018 research on the evaluation of the KKBP program were seen from 4 aspects, namely effectiveness, adequacy, equity, and accuracy. The effectiveness of the KKBPK program in reducing maternal mortality is carried out through the "Four Too" socialization. The adequacy of the KKBPK program is still constrained in terms of human resources and budget/costs. However, so far, to overcome these obstacles, the government is collaborating with third parties such as the community, NGOs, and even other agencies in order to be able to meet their shortcomings. Equity is seen from the government's efforts to distribute family planning facilities in the form of service clinics, but the number of clinics between sub-districts is still different. Aspects of accuracy in terms of technical feasibility, economic feasibility, political feasibility and administrative feasibility tend to be appropriate in dealing with the population problems of Semarang City (Muchlis S and Maron A, 2018).

Based on Angisna T's research in 2018 in general, assessment in training is carried out after 3 months after the training is given. This is done to provide opportunities for participants to be able to implement the lessons learned during the training in the field. The level of success of a training can be evaluated thoroughly based on several criteria, including success criteria which include the opinions or perceptions of participants, change criteria which include assessment of changes in attitudes, work behavior, and success criteria which are assessed based on the performance of training participants. Pre-test and post-test of participants after job training can be fundamental to the design of further training development (Angisna T, 2018).

This is in accordance with the conceptual framework which states that the evaluation of the success of the KKBPK program is influenced by the Monitoring and Assessment Factor. It states to supervise the KKBPK program in order to find out the shortcomings of the program and to immediately repair it, for an assessment of the KKBPK program in order to evaluate the program and immediately improve it to become a a better program, it has an important role in supporting and supporting the running of the Kampung KB Program.

\section{G. Evaluating KKBPK Program Feedback}

The results of Muchlis S and Maron A's research in 2018 that the city government's responsiveness has a high commitment to solving population and family planning problems. Regarding the Population Family Planning and Family Development program, it is considered good enough to satisfy the target group, namely the community, but it is undeniable that there are still people who are difficult to invite to family planning for various reasons. From the youth side, there is still very little interest in being involved in the success of the population program by doing positive activities by holding associations or other positive activities (Muchlis S and Maron A, 2018). As for the community response, according to research by Resnawaty R, Humaedi S, and Adiansah W in 2018. The community's response to various programs and activities of Kampung KB is basically good. Although there are still some community members who are indifferent to Kampung KB. This is a challenge for $\mathrm{KB}$ Village cadres and administrators to change the negative behavior of the community so that they are more concerned and can participate more actively in various KB Village programs and activities (Resnawaty R, Humaedi S, and Adiansah W, 2018).

The evaluation of the KKBP program is seen from the Responsiveness Aspect, namely the general public's point of view is already good, but there are still people who are difficult to invite to family planning. In addition, the responsiveness of adolescents is still very minimal and must be improved (2). Based on research by Mandas IST, Lengkong FDJ, and Ruru J in 2018, things that make it difficult for people to do family planning are complaints that are often raised by the community usually regarding the cost of family planning services which are not completely free for family planning services for the poor (KPS and KS-I). and also complaints about contraceptive devices and drugs, but what they should be aware of is that free family planning services for the poor basically include the provision of free contraceptive devices and drugs only for family planning participants from KPS and KS (Mandas IST, Lengkong FDJ, and Ruru J, 2018) . Therefore, the expected impacts of holding these programs are increasing public awareness of the stunting problem and its prevention, creating environmental conditions that support the 1000 HPK strengthening program as stunting prevention, and creating a sense of unity that is able to strengthen residents in the formation of family planning villages and strengthening PIK-R (Tentama F, Delfores HDL, Wicaksono AE et al, 2018).

This is in accordance with the conceptual framework which states that the evaluation of the success of the KKBPK program is influenced by the Feedback Factor stating that knowing the responses / responses from respondents or the community to the program being implemented can identify the shortcomings of the program and can be followed up immediately, it has an important role in supporting and support the implementation of the KB Village Program.

H. Evaluating the Community Satisfaction Index of the KKBPK Program

According to research by Zuhriyah A, Indarjo S, and Raharjo BB in 2017 after the family planning village program was running, there was already satisfaction of families and community members with the development of family planning villages. However, this satisfaction is not great because there are still many things that need to be addressed and improved in family planning village activities (Zuhriyah $\mathrm{A}$, Indarjo $\mathrm{S}$, and Raharjo BB, 2017). In addition, according to research by Simanjuntak I, Nugraha T, and Somanjorang A in 2020, the low 
performance and job satisfaction of PLKB is because what the organization needs is not met properly. The low work motivation of PLKB officers will have an impact on the achievement of family planning coverage. High job satisfaction will encourage increased individual and group performance, which in turn will increase the overall effectiveness of the company (Simanjuntak I, Nugraha T, and Somanjorang A, 2020).

This is in accordance with the conceptual framework which states that the evaluation of the success of the KKBPK program is influenced by the Community Satisfaction Index.

\section{CONCLUSION}

Based on the results of the literature review, found 17 articles that discuss Human Resources (HR), facilities and infrastructure, financing, planning accuracy, implementation mobilization, monitoring and assessment, feedback, community capacity index in the Population, Family Planning, and Family Development programs (KKBPK).

\section{REFERENCES}

Angisna T. 2018. Evaluasi efektivitas pelatihan kampung KB di perwakilan BKKBN Provinsi Jawa Timur. Jurnal Promkes; 6(1): 93-103.

Awan, H. M., Bukhari, K. S., \& Iqbal, A. (2011). Service quality and customer satisfaction in the banking sector: A comparative study of conventional and Islamic banks in Pakistan. Journal of Islamic Marketing.

BKKBN. 2020. Artikel: Menyongsong Wajah Baru Program KKBPK Menuju Tahapan Renstra BKKBN 2020-2024. Diakses dari https://www.bkkbn.go.id/detailpost/menyongsongwajah-baru-program-kkbpk-menuju-tahapan-renstrabkkbn-2020-2024 tanggal 21 Maret 2020.

Handayani A, Najib, Ardini SN, dkk. 2020. The Evaluation Studies Of Kampung Kb In Central Java. Jurnal Kesejahteraan Keluarga dan Pendidikan; 7(1): 63-73.

Istiadi A, Rosdiana W. 2012. Implementasi program kampung keluarga berencana (studi pada kelompok sasaran keluarga dengan remaja di Dusun Waung Desa Sonoageng Kecamatan Prambon Kabupaten Nganjuk). eJournal Administrasi Negara; 1(1): 1-8.

Januar, A.S. 2020. Artikel: Sosialisasikan Program KKBPK ternyata ini Tujuan BKKBN. Diakses dari https://jatim.tribunnews.com/2017/10/20/sosialisasikanprogram-kkbpk-ternyata-ini-tujuan-bkkbn?page $=2$ tanggal 21 Maret 2020.

Khotimah K, Ratnasari V, Ratna M. 2018. Pengelompokkan kelurahan di Kota Surabaya berdasarkan kriteria pembentukan kampung keluarga berencana. Jurnal Sains dan Seni ITS; 7(2): 2337-3520.

Lettiyani E, Isabella, Kencana N. 2020. Implementasi program kampung keluarga berencana (KB) di Desa Sribunga Kecamatan Buay Pemuka Bangsa Raja Kabupaten Ogan Komering Ulu Timur (OKUT). Jurnal Pemerintahan dan Politik; 5(3): 1-9.
Mandas IST, Lengkong FDJ, Ruru J. 2018. Evaluasi kebijakan kependudukan program keluarga berencana di Provinsi Sulawesi Utara. Jurnal Administrasi Publik; 4(62): 9298.

Mauluddin A, Novianti. 2020. Peran program kependudukan, keluarga berencana, dan pembangunan keluarga (KKBPK) dalam menurunkan prevalensi stunting. Jurnal Reproduksi; 2(1): 1-12.

Muchlis S, Maron A. 2018. Evaluasi program kependudukan keluarga berencana dan pembangunan keluarga (kkbpk) dalam menekan angka kematian ibu di Kota Semarang. Journal Of Public Policy And Management Review; 2(7): 897-902.

Raharjo EG, Salomo RV. 2019. Implementasi kebijakan pengukuran kinerja penyuluh program kependudukan keluarga berencana dan pembangunan keluarga (KKBPK) melalui aplikasi E-Visum di perwakilan BKKBN Provinsi Banten. Jurnal Reformasi Administrasi; 6(2): 98-106.

Ramdana S, Kusuma AR, Apriani F. 2018. Implementasi program kependudukan, keluarga berencana dan pembangunan keluarga (KKBPK) bidang ketahanan dan kesejahteraan keluarga pada Kelurahan Temindung Permai Kota Samarinda. Ejurnal Administrasi Negara; 6(3): 8021-8034.

Resnawaty R, Humaedi S, Adiansah W. 2018. Evaluasi program kampung keluarga berencana dalam meningkatkan ketahanan dan kesejahteraan keluarga. Jurnal Kolaborasi Resolusi Konflik; 3(1): 93-104.

Rianto F, Nengsih NS, Setyadiharja R. 2019. Evaluasi program kampung keluarga berencana di kota Tanjungpinang. Jurnal Dimensi; 8(2): 286-306.

Simanjuntak I, Nugraha T, Simanjorang A. 2020. Analisis kemampuan petugas penyuluh lapangan keluarga berencana (plkb) dalam melaksanakan program kependudukan keluarga berencana dan pembangunan keluarga (KKBPK) di Kabupaten Tapanuli Utara tahun 2018. Journal of Pharmaceutical and Health Research; 1(2): 54-61.

Sudarmi, 2020. Artikel: Upaya Peningkatan Kualitas Penduduk Melalui Program Kependudukan Keluarga Berencana dan Pembangunan Keluarga (KKBPK). Diakases dari https://pengasih.kulonprogokab.go.id/files/artikel\%20k b.pdf tanggal 21 Maret 2020.

Tentama F, Delfores HDL, Wicaksono AE, dkk. 2018. Penguatan keluarga sebagai upaya menekan angka stunting dalam program kependudukan, keluarga berencana dan pembangunan keluarga (KKBPK). Jurnal Pemberdayaan: Publikasi Hasil Pengabdian kepada Masyarakat; 2(1): 113-120. 
Yunus NS, Nailufar FD. 2019. Collaborative governance melalui program kampung KB di Kabupaten Jombang. Jurnal Ilmu Pemerintah; 5(2): 162-173.

Zuhriyah A, Indarjo S, Raharjo BB. 2017. Kampung keluarga berencana dalam peningkatan efektivitas program keluarga berencana. Jurnal Higeia; 1(4): 1-13.

\section{AUTHORS}

First Author - Agung Biworo, Medical Education Study Program, Faculty of Medicine, Lambung Mangkurat University, Indonesia

Second Author - Lenie Marlinae, Public Health Study Program, Faculty of Medicine, Lambung Mangkurat University, Indonesia

Third Author - Syamsul Arifin, Public Health Study Program, Faculty of Medicine, Lambung Mangkurat University, Indonesia

Fourth Author - Laily Khairiyati, Public Health Study Program, Faculty of Medicine, Lambung Mangkurat University, Indonesia

Fifth Author - Agung Waskito, Public Health Study Program, Faculty of Medicine, Lambung Mangkurat University, Indonesia

Sixth Author - Anugrah Nur Rahmat, Public Health Study Program, Faculty of Medicine, Lambung Mangkurat University, Indonesia

Seventh Author - Herty Sasmieta, Faculty of Medicine, Lambung Mangkurat University, Indonesia

Eighth Author - M Gilmani, Public Health Study Program, Faculty of Medicine, Lambung Mangkurat University, Indonesia

Ninth Author - Winda Saukina Syarifatul Jannah, Public Health Study Program, Faculty of Medicine, Lambung Mangkurat University, Indonesia

Tenth Author - Raudatul Jinan, Public Health Study Program, Faculty of Medicine, Lambung Mangkurat University, Indonesia

Correspondence Author - Lenie Marlinae, Public Health Study Program, Faculty of Medicine, Lambung Mangkurat University, Indonesia, Email: bintangara@ulm.ac.id 